\title{
Transmission and Innovation of Kasidah (Lagu Islam) in Indonesian (1975 ) Take a Case Study on Nasida Ria Kasidah Modern in Semarang
}

\section{Hung, Ning-Hui}

Post Graduate Program, Indonesian Institute of the Arts Yogyakarta

\begin{abstract}
Indonesian Islamic music has its own performance occasion, musical function, music characteristic, and the style of musical performance. It has lyrics that represent direct relationship between Moslems and God in religion ceremonies. However, the musical structures are changed due to external stimulation coming along with the changes of Indonesian social structure during its development especially in 1975. Kasidah, a sort of Indonesian Islamic music, is the best exemplification to manifest the interaction between social development and music cultural changes, peculiarly performed by the music group of Qasidab Modern Nasida Ria in Semarang, Indonesia. The reason is that kasidab is more liberal than other Islamic music genres in Indonesia, especially on musical performance, usage on instruments, etc. This research sees "music" as a communication system of sound which passes through social usage and cultural contexts in Ethnomusicological perspective. The focus of discussion in on this group to explore some topics in order to comprehend the interaction between social structural development and the innovation of kasidah musical structure in Indonesia, such as the transmission and development of the group Qasidah Modern Nasida Ria, innovation of the group Qasidab Modern Nasida Ria and its music, and the musical function of modern kasidah. By which to understand the current development of kasidab in Indonesia, explore the concept and the role of the word 'modern' plays in the development of modern kasidah, and point out the cultural syncretism and impact occured in the development of modern kasidah.
\end{abstract}

Keywords: indonesian islamic mucic, kasidah (Qasidab), innovation, transmission 


\section{INTRODUCTION}

Religious music includes two parts of 'music' and lyrics. Lyrics reflect religious beliefs. Music reflects the interaction between social development and music structure because musical structures are changed by their outside stimulation during their development. Undoubtedly, such a change on music structure is a suitable way for music culture to adapt itself to the new conditions. Also, this is the way by which they can avoid being eliminated in such a new environment.

Kasidah (Arab: "ق صد", Qasidah, qasida), a sort of Indonesian Islamic music, is the best exemplification to manifest the interaction between social development and music cultural changes, especially for the group of Nasida Ria Kasidah Modern in Semarang Indonesia. This group was the first performing the kasidah with popular music structure in Indonesia. Its establishment not only affected a great deal of Islamic music tending to be popular but also encourages plenty of Islamic music groups playing popular music to be built.

Actually, Kasidab that originated from the Arabian and had existed before the coming of Islam is a kind of Arabic literature poetry in the Arabia Peninsula. However, during the historical development, its performance formation has had some changes with different conditions no matter in the period of pre-Islam and Islam, or in the country of Indonesia. The following will introduce the type and function of kasidab in Islamic transmission from Arabia to Indonesia, Indonesian kasidah musical formation, and then take Nasida Ria Kasidah Modern group for instance to explore the interaction between musical structure and social development.

\section{Development and musical formation of kasidah}

Culture is the accumulation of people's lives and experiences. Music, or one of the parts of culture, not only shows the way of people's lives, but even more be served as a concept and behavior which has the same function as a culture reality. For many people, music is not only a concept which people presents, but also a symbolic system of national identification.

It is the differences between people that culture, concepts and customs are different in each place. However, immigrating is one of the very basic ways to spread culture, by which cultures start to be learned and imitated from one to another. Also, it makes Qasidah, originated in Arabia, change into a form of music from a kind of Arabian poetry after Qasidah coming in Indonesia and combine with the musical concepts of Indonesian Moslems. 
related to Islam, i.e. Islamic sources. In other words, any topic which was criticized, stated or expressed on Islamic viewpoint could be involved in the content of Qasidah, like political issues, praises of God, Qasidah was emphasized to be a medium to praise the Prophet in Mamalik Dynasty (685-705 A.D.) of Umayyads period (661-750 A.D.) crimes or personal problems, etc. Secondly, Qasidah became a facility which was used to reach a purpose or goal, especially to propagate Islamic doctrines, and to praise Allah and the Prophet. Accordingly, Qasidah, one style of Arabian poetry, became a medium used to propagate Islam and praise God in Islamic period.

\subsection{Kasidah in Indonesia}

The time about the spreading of Qasidah to Indonesia can be concluded that Qasidah originated in Arab might directly or indirectly be introduced to Indonesia through Malaysia in the 1960s. However, it will cause cultural changes when a tradition, or a language pattern, religious belief or literature which has a long historical development, comes in a new cultural context and constantly contacts with the other one over there.

Thus, a series of cultural contacts and influences would take place on the development of Qasidah after Qasidah came to Indonesia. Also, some cultural changes would take place on Qasidah after Qasidah was integrated into Indonesian cultural context. Today, Qasidah has been one part of Indonesian culture. There are four points gathered in the following statement, for readers to comprehend the development situation of Qasidab being integrated in Indonesian music cultural context.

Firstly, the Arabic word of Qasidah is absorbed by Indonesian language system, namely it is replaced by the Indonesian vocabulary of kasidab. That is the first cultural change happening to Qasidah after Qasidah came to this country. Even though many documents related to such a music culture are written in the word of kasidah, there are a few papers still be written in Qasidah in Indonesia. Secondly, kasidah is transformed into a music genre expressed by singing from a literature of Arabian poetry in order to accommodate itself to Indonesians' common practice on music. It is performed mainly by an ensemble which consists of several female Moslems dressing formally with scarf (jilbab) and simultaneously accompanied by the percussion instruments of rebana. The main purpose performing kasidab is to amuse the audience and simultaneously to propagate Islamic doctrines.

Thirdly, kasidah provides a very wide range for people to create its content, namely either topic related to Islamic or praise of God can be involved in. Its content can either be created by Moslems themselves or be selected from religious books written by Islamic 
scholars (ulama). Fourthly, kasidah can be created in any language, either in Arabic, Indonesian or each local language. For most part Indonesian, kasidab lyrics written in Arabic are a little bit difficult for them to comprehend except they have got experiences in learning Arabic (a lot of Islamic education institutes (pesantren) set up kasidah groups chanting in Arabic inside of institute to promote students' Arabic language ability in Indonesia). Thus, kasidah always be created in Indonesian or local language in Indonesia in order to let people really comprehend the meaning of chanting lyrics and easily propagate Islamic doctrines. Accordingly, it is because of its creation style that kasidah (or Qasidab) should not to follow Arabic poetry meters when creating.

\subsection{Musical structure}

Kasidah performance mainly consists of different sizes of rebana-s (sometimes called terbang in Javanese) and singers. Its instrumental ensemble mainly consists of several rebana-s with small, middle and big size (a). That is the basic organization of kasidah instrumental ensemble, and also an instrumental organization of a small kasidah group. Certainly, the number of instrument will be increased with the degree of ensemble organization be expanded.

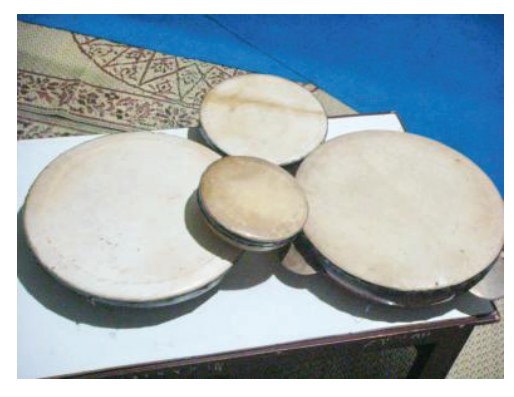

(a) rebana-s percussion instruments.

The beat of rebana is the basic musical element of kasidah. Not only does the music structure become varied but the plays and singers also are informed how to perform the song by varying the beats. Rebana-s controls the performance of song, especially for rebana sedang (b), and accompanies it with steady tempo when performing.

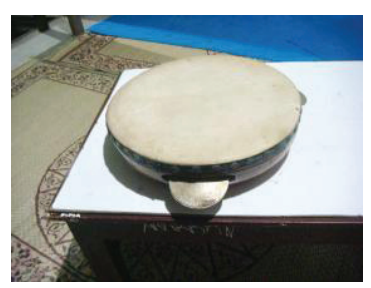

(b) rebana sedang.

Undoubtedly, each instrument has a notation which conforms to the range and structure of instrument to record the musical sounds in order to make players easily to read and 
perform. Accordingly, the notation of rebana percussion instrument mainly consists of several symbols originated in the sounds when rebana be beat, such as $\mathrm{p}$ (or b), t, br, etc. Also, the symbol $\bullet$ means a rest in notation.

Those above-mentioned symbols not only comprise the rhythm pattern of a basic kasidah ensemble (c), but also become the basic musical elements of kasidab notation. Also, this rhythm pattern playing with different speeds and different formations becomes kasidah accompaniment music.

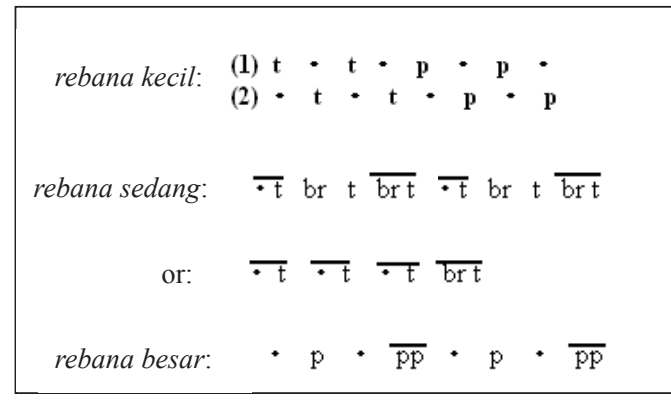

(c) rhythm pattern of rebana

\section{Nasida Ria Kasidah Modern group and the development of Indonesian society}

\subsection{Modernized development and stimulations on Indonesian society}

Western has become not only a powerful country but also a powerful culture in the world because of the rise of Western Industrial Revolution, Capitalism and Colonialism in the late 19th and early 20th centuries. Also, it has been a chain of changes in which no matter Africa, Asia or Europe joins because it not only influences the development of social structure, political and cultural system in each place, but also provides opportunities for each traditional music culture to imitate and contact with Western music culture. Actually, this chain is an evolution changing from traditional to modernized, that is, all the traditions in people's lives are more or less, sooner or later, willingly or forcedly leave from the inside of tradition. No countries or nations can completely resist this temptation of modernization although people still strongly feel attachment to tradition. The power of modernization is unknowingly changing and influencing people's value systems and cultural orientation (Yeo- Chi King 1992:125).

Nevertheless, a non-Western society can be led to either a Western model or a non-Western model. Also, each society has different traditional characteristics and different starting points of being modernized. Hence, it is impossible that a society will totally be 
westernized under the leading of modernized development. Accordingly, it can be said that what exists between each society is parts of similar characteristics, or modernity, i.e. the distinctive color of Western-style society and nation, under the leading of modernized development. Thus, the word modernization is more appropriate and significant than westernization although the definition is very similar between the two.

Actually, the first time Indonesia suffering the influences of Western powers can be dated back to the sixteenth-century when the Dutch and Portuguese came to Indonesia for managing local amazing diversity of spice resources. From this moment, Western powers have been spreading throughout Indonesia and influencing the development of Indonesian social and economic structures; in other words, it can be said that this moment is the beginning time Indonesia moving towards the metamorphosis process of modernized development. Although the Western successively entered into Indonesia for nothing but the management for spices, they focused on trade developments and the circulation of commodities in early days. With the coming of the Western starting that moment, so far, the development of Indonesian political affairs, economics, science and technology, and culture has greatly influenced by Western; especially after declaring their independence in 1945, modernization and westernization has moved like wildfire.

On music cultural development, however, so far, diversified western popular music elements coming with modernization and westernization have been not only influencing the development of Indonesian traditional music culture but also bringing them some degree of threats. Such being the case, culture change is the best way for traditional music culture to seek the value of survival in the times of modernization and westernization.

\subsection{The development of Nasida Ria Kasidah Modern group}

The impact of Western modernization and westernization on Indonesian traditional music culture also reflects on the development of Islamic music culture. As far as the group Nasida Ria Kasidab Modern is concerned (d), it was established by H.M. Zain in 1975 in Kauman Semarang in Indonesia. It is the first kasidah group in Indonesia practicing modernity and popularization in the development of ensemble and music structure by culture change. In such a modernized society flooding with western popular music elements, this cultural metamorphosis process, i.e. culture change, not only closes the distance between traditional music culture and western popular music but also gives such a renewed musical culture a new life and significance in this modern society. 


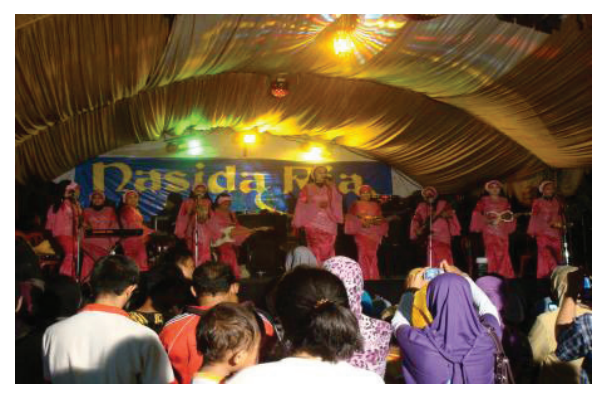

(d) Nasida Ria Kasidah Modern group.

Under the development of music industry, Indonesian society in the year of $1975 \mathrm{had}$ already flooded with various popular music elements where H.M. Zain hit upon an idea of setting up a religious group corresponding with contemporary popular music characteristics.

In a literal sense, the title Nasida Ria combining Arabic Nasida, 'songs', with Indonesian Ria, 'cheerful or pleasant' means 'songs be used to try to please someone', which just corresponds with the main musical feature of kasidah. For creating so-called modern kasidah corresponding with contemporary popular music characteristics, the composers of Nasida Ria Kasidah Modern combine popular music cultural elements with basic elements of kasidab in order to make this group present modernity no matter on formation or on music structure, which is also the main development guiding principle of this group.

\section{Kasidah musical cultural change}

\subsection{Changes in instrumental organization}

\section{Modern instruments}

Cultural change is caused by either its social structural change or the connection between different nations. Anthropologist asserts that cultural change is a condition where culture can avoid being discarded forever; namely, only by where, culture will not become obsolete.

Kasidah consisting of religious and musical elements has been one of Indonesian traditional musical culture. In order to adapt to the present condition, the group Nasida Ria Kasidah Modern makes some innovations to kasidah, by which not only changes its original musical formation but also gives it new vitality in such a modern environment.

What be called electronic instrument is a musical instrument which produces its sounds using electronics, like the electronic guitar, electronic piano, music synthesizer, etc. However, in Indonesia, those instruments are chiefly used in modern popular music and 
played by the young. They are deeply attracting the young, and bring people a feeling of modern.

This group adds several electronic instruments for showing strong modern characteristics on instrumental organization and presenting the melodies and sound effects being similar to popular music on music. Those electronic instruments were widely used in popular music and known by people very much at that time, by which not only can successfully achieve the purpose of instrumental change but also can make people easily accept such an instrumental change.

Those electronic instruments, indeed, change the original instrumental organization of kasidah group and greatly improve melody of songs. However, on the other hand, they also influence not only kasidah musical notation but also the dominance of rebana sedang in kasidah ensemble.

\subsubsection{Cords musical notation}

Undoubtedly, music notation is a general form to describe the writing down of music for players to read in performances. It records music, and also reflects musical structure. Accordingly, when composing music, composer uses cords musical notation to write down the melodies played by those electronic instruments instead of the original kasidah notation consisting of varied rebana beats (e).

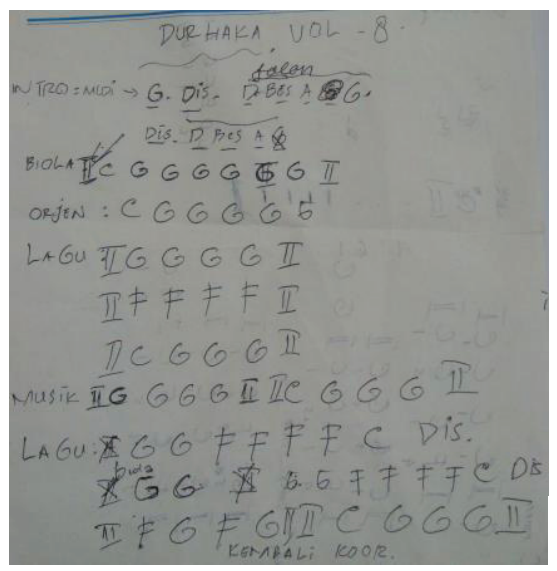

(e) Cords musical

\subsubsection{Electronic piano dominates ensembles}

Electronic piano replaces the leading role of rebana sedang in kasidab ensemble and controls the whole ensemble because it not only can completely play musical melodies and chords but also is the main backbone of musical chords of all melodic instruments. Thus, the role of rebana sedang is changed from original function of controlling rebana beats to a specific sign in group, which represents both a relationship relating with Islam and an existence of 
the essence of kasidah musical culture. Nevertheless, such a change on rebana is a necessary phenomenon during the process of cultural acculturation.

\subsection{The source and characteristics of lyrics}

Kasidab's lyric creativity and language usage are liberal. On the creativity and development of lyrics, firstly, Nasida Ria Kasidab Modern group emphasizes the source of their lyrics is diversified. In other words, their lyrics can not only originate from any Islamic religious books, but also be newly-created from Islamic religious viewpoint. Secondly, on the use of language, they make Indonesian become the main language in performing.

Accordingly, for audiences, the lyric of modern kasidah is easy to understand, easy to memorize, and easy to sing. Also, it has some characteristics being similar to common popular music: lyric is easy to understand, and song is easy to sing and memorize.

\section{CONCLUSION}

Cultural change is a necessary process for a traditional culture to adapt itself to a new condition. Thus, there are some changes taking place on Qasidab in Islamic transmission from Arabia to Indonesia. The Arabic word of Qasidab is absorbed by Indonesian language system, i.e. kasidah. Also, it becomes a music genre expressed by singing from Arabic literature and simultaneously accompanies with rebana-s percussion instruments.

Under the impact of modernization and westernization, many kasidah music followers gradually turn to the arms of common popular music due to they are not strong enough to hold back its glamour, and then make many kasidah groups become decline and decay gradually. Such being the situation, Nasidah Ria Kasidah Modern group makes their music structure become popularized in order to give kasidah a new life-force and meaning in present society, that is so-called modern kasidah.

Modern kasidah is the result of Indonesian kasidah musical culture change. In other words, kasidah takes some changes on its development on the basis of its traditional music elements and by the way of innovation in order to accommodate itself to this modern society. By which, modern kasidah not only has the characteristic being similar to common popular music, but also remains the cultural essence of kasidah, i.e. the beats and instrument of rebana.

Undoubtedly, innovation is a way, by which modern kasidab looks like common popular music no matter on its language or music practice. In spite of that, for Indonesian Moslems, 
kasidah music is a medium being used to propagate Islamic beliefs. Accordingly, the popularized music structure of modern kasidah can be said that it is a medium fitting in with contemporary cultural value and being used to propagate Islamic beliefs.

\section{REFERENCES}

Tsung-Te Tsai. 2002. The world of Islamic music and culture. Taipei: Wu Nan.

Tsung-Te Tsai. 2006. Tradition and Modernity of Islamic Music Culture in Indonesia. Taipei, Taiwan: Gui-Guan.

Yeo-Chi King. 1992. From Traditional to Modernized. Taipei, Taiwan: Shi-Bao.

Blaukopf, Kurt. 1992. "The Mediamorphosis of Music as Global Phenomenon, Musical Life in a Changing Society". Portland: Amadeus Press.

Bart Barendregt and Wim van Zanten. 2002. "Popular Music in Indonesia since 1998, in Particular Fusion, Indie and Islamic Music on Video Compact and the Internet," Yearbook for Traditional Music, Vol. 34: 67-113. Publisher: International Council for Traditional Music.

Geertz, Clifford. 1973. The Interpretation of Cultures. New York: Basic Book.

John Blacking. 1977. "Some Problems of Theory and Method in the Study of Musical Change," Yearbook of the International Folk Music Council, Vol. 9: 1-26. 